\title{
KECERDASAN VISUAL SPASIAL DAN KEMANDIRIAN BELAJAR PADA HASIL BELAJAR MATA PELAJARAN GAMBAR TEKNIK DI SMK
}

\author{
Muhammad Arif Wahyudi \\ Widiyanti \\ Didik Nurhadi
}

\begin{abstract}
Abstrak: kecerdasan visual spasial memiliki pengaruh signifikan pada menggambar teknik yang didukung oleh faktor kemandirian siswa dalam proses belajar. Selanjutnya, penelitian ini bertujuan untuk mengetahui hubungan kecerdasan visual spasial dan kemandirian belajar terhadap hasil belajar siswa pada mata pelajaran Gambar Teknik. Desain penelitian ini adalah korelasi dengan pendekatan kuantitatif. Subjek penelitian ini adalah 82 siswa kelas X Teknik Pemesinan di SMK Turen. Teknik pengumpulan datanya adalah tes, angket, dan dokumentasi. Analisis datanya menggunakan statistik regresi linier dan berganda. Hasil penelitian menunjukkan bahwa kecerdasan visual spasial dan kemandirian belajar siswa tergolong tinggi pada mata pelajaran Gambar Teknik. Masing-masing variabel memiliki hubungan dan pengaruh terhadap hasil belajar siswa. Ini ditunjukkan oleh nilai hasil belajar siswa yang berkriteria tinggi. Sehingga, ini dapat disimpulkan bahwa masing-masing variabel secara simultan berpengaruh positif terhadap hasil belajar.
\end{abstract}

Kata-kata Kunci: kecerdasan visual spasial, kemandirian belajar, hasil belajar

\begin{abstract}
Spatial Visual Intelligence and Independence Learning toward the Learning Result on the Subject of Technique Drawing in Vocational High School. Spatial visual intelligence has a significant influence on drawing techniques that are supported by student independence in the learning process. Furthermore, this study aims to determine the relationship of visual-spatial intelligence and learning independence to students' learning result in the subject of Engineering Drawing. This research design was a correlation with a quantitative approach. The subjects of this study were 82 students of class X Machining Engineering in Turen's Vocational High School. Data collection techniques were tests, questionnaires, and documentation. Data analysis used linier and multiple regression statistics. The results showed that visual-spatial intelligence and student learning independence were high in the subject of Engineering Drawing. Each variable had a relationship with and influence on student learning result. This was indicated by the high value of student learning result. So, it can be concluded that these variables simultaneously have a positive effect on learning result.
\end{abstract}

Keywords: visual spatial intelligence, learning independence, learning result

$\mathrm{S}$

alah satu upaya untuk membangun sumber daya manusia, yaitu dengan

atau Sekolah Menengah Kejuruan (SMK). Penyelenggaraan pendidikan memenyelenggarakan pendidikan kejuruan nengah kejuruan bertujuan untuk

Mohammad Arif Wahyudi adalah Mahasiswa Jurusan Teknik Mesin Universitas Negeri Malang. Email: arifwahyu0910@gmail.com. Widiyanti dan Didik Nurhadi adalah Dosen Teknik Mesin Universitas Negeri Malang. Alamat Kampus: Jl. Semarang No. 5 Malang 65145. 
meningkatkan kecerdasan, pengetahuan, kepribadian, ahklak mulia, serta keterampilan untuk hidup mandiri dan siap bekerja sesuai dengan bidangnya serta menguasai kompetensi program keahlian dan kewirausahaan baik untuk memenuhi tuntutan dunia kerja maupun untuk mengikuti pendidikan tinggi sesuai dengan kejuruannya (Permendiknas No. 23 Tahun 2006). Kompetensi sumber daya manusia merupakan salah satu tujuan penting dari diselenggarakannya pendidikan menengah kejuruan. Kompetensi dalam hal ini yaitu sebagaimana dijelaskan dalam ketentuan Direktorat Pembinaan SMK (2018) yaitu suatu spesifikasi pengetahuan dan keterampilan serta penerapan dari pengetahuan dan keterampilan tersebut setingkat dengan industri pada standar kinerja yang dipersyaratkan dalam pekerjaan.

Di bidang manufaktur, kemampuan dan keterampilan dalam membuat dan membaca gambar teknik sangat diperlukan karena tanpa kemampuan tersebut siswa akan mengalami kesulitan dalam membuat suatu produk. Hal tersebut senada dengan yang diungkapkan oleh Suratman (2000), bahwa kemampuan membuat dan membaca gambar merupakan hal sangat penting untuk seorang ahli teknik. Membaca gambar teknik adalah salah satu mata pelajaran yang terdapat dalam kurikulum di SMK Turen Kelas X Program Keahlian Teknik Pemesinan. Dalam proses pembelajarannya banyak dijumpai siswa yang mengalami kesulitan dalam mempelajari mata pelajaran gambar teknik, sehingga berdampak kepada hasil belajar siswa tersebut.

SMK Turen merupakan lembaga pendidikan formal kejuruan yang berhubungan dalam mengembangkan keterampilan siswanya agar menjadi manusia yang produktif, memiliki hard-skills dan soft-skills yang mampu bersaing dalam dunia kerja, dan memiliki kompetensi sesuai dengan bidang keahlian yang dipilihnya. Dengan dimilikinya suatu kompetensi tertentu, lulusan SMK Turen diharapkan dapat memenuhi kebutuhan dunia kerja baik di dalam maupun luar negeri. Salah satu keterampilan penting yang harus dimiliki siswa Program Keahlian Teknik Pemesinan di SMK Turen adalah Menggambar Teknik.

Berdasarkan hasil observasi yang dilakukan di SMK Turen selama kegiatan Kajian Praktik Lapangan (KPL) pada bulan Januari dan Februari 2018 di kelas X Teknik Pemesinan, siswa mengalami kesulitan untuk memahami objek atau gambar jobsheet yang diberikan oleh guru sehingga hasil gambar yang dikerjakan siswa tidak sesuai. Selain itu, kurangnya kesadaran dalam diri siswa dalam belajar mandiri yaitu kemauan untuk belajar secara individu tanpa diperintah oleh siapapun baik di sekolah maupun di rumah. Hal ini menyebabkan prestasi belajar siswa menjadi rendah dan dapat dibuktikan dengan rekap nilai jobsheet menggambar proyeksi yang hampir sama dengan nilai Kriteria Ketuntasan Minimal (KKM).

Rendahnya prestasi siswa diakibatkan oleh faktor intrinsik diantaranya adalah kecerdasan dan kemandirian belajar. Menurut Gardner (1993), kecerdasan visual spasial adalah kecerdasan untuk menangkap dunia ruang secara tepat atau dengan kata lain kecerdasan untuk memvisualisasikan gambar yang di dalamnya termasuk mengenal bentuk dan benda secara tepat, melakukan perubahan suatu benda dalam pikirannya dan mengenali perubahan tersebut, menggambarkan suatu hal atau benda dalam pikiran dan mengubahnya dalam bentuk nyata, mengungkapkan data dalam suatu grafik serta kepekaan terhadap keseimbangan, relasi, warna, garis, bentuk, dan ruang. Kecerdasan visual spasial, disana perlu adanya pemahaman kiri-kanan, pemahaman perspektif, bentuk-bentuk geometris, menghubungkan konsep spasial dengan angka dan kecerdasan dalam transformasi mental dari bayangan visual. 
Selanjutnya tiga indikator kecerdasan spasial, yaitu imajinasi, konseptualisasi, dan pemecahan masalah (Cocodia, 2014; Novitasari dan Rahman, 2015; Rimbatmojo, Kusmayadi dan Riyadi, 2017). Hasil penelitiannya mengemukakan bahwa sebagian besar siswa belum sepenuhnya dapat memecahkan masalah membangun ruang sisi datar sehingga hal ini dapat mempengaruhi hasil belajar yang diperoleh oleh siswa sendiri. Kecerdasan visual spasial yang tinggi akan mempermudah siswa dalam memahami obyek geometri karena memiliki kemampuan untuk merasakan dunia spasial secara akurat (Riastuti, Mardiana, dan Pramudya, 2017). Hal ini menunjukkan bahwa kecerdasan visual spasial memiliki pengaruh yang tinggi dalam menggambar teknik.

Sementara itu, kemandirian belajar juga termasuk salah satu faktor yang mempengaruhi hasil belajar. Kemandirian belajar merupakan aktivitas belajar yang berlangsungnya didorong oleh kemauan sendiri, pilihan sendiri, dan tanggungjawab sendiri dari pembelajar (Tirtarahardja dan Sulo, 2008). Menurut Sumarno (2004) bahwa karakteristik yang termuat dari kemandirian belajar, yaitu individu merancang belajarnya sendiri sesuai dengan keperluan atau tujuan individu yang bersangkutan, individu memilih strategi dan melaksanakan rancangan belajarnya, dan individu memantau kemajuan belajarnya sendiri serta mengevaluasi hasil belajarnya dan dibandingkan dengan standar tertentu. Peran kemandirian sangat diperlukan bagi setiap siswa dalam proses belajar terutama saat siswa belajar secara individu. Saat ini sangat jarang ditemukan para siswa belajar di rumah dengan kemauan dari dalam diri sendiri. Kurangnya sikap kemandirian belajar siswa dapat dilihat dari kenyataan yang ada bahwa siswa bergantung kepada temannya dalam mengerjakan tugas kelompok dan menyontek pada saat me- ngerjakan ulangan dan tugas sehingga hal ini menyebabkan hasil belajar siswa kurang optimal (Pangestu, 2017).

Berdasarkan hasil observasi selama proses pembelajaran mata pelajaran Gambar Teknik I Kelas X Teknik Pemesinan SMK Turen ditemukan adanya permasalahan dalam memahami konsep hubungan keruangan yang dalam hal ini berkaitan dengan kecerdasan visual spasial mereka. Permasalahan ini mengakibatkan kegagalan siswa dalam memahami konsep gambar nantinya, karena siswa yang mengalami ini tidak dapat menangkap maksud dari gambar tersebut. Selain itu kemandirian belajar siswa masih rendah, hal ini terlihat kebiasaan belajar siswa dan kurangnya keaktifan siswa selama kegiatan belajar. Mayoritas siswa belajar ketika guru menyuruh, menunggu, dan mengajukan pertanyaan kepada siswa. Siswa kurang menyadari pentingnya untuk belajar secara mandiri jika tidak ada guru. Apabila rendahnya tingkat kecerdasan visual spasial dan kemandirian belajar dilakukan terus menerus oleh siswa maka ini dapat berpengaruh pada hasil belajar yang dicapainya.

Tujuan penelitian ini dilakukan untuk mengetahui hubungan dan pengaruh kecerdasan visual spasial dan kemandirian belajar terhadap hasil belajar siswa pada mata pelajaran Gambar Teknik I di SMK Turen. Harapannya, hasil penelitian ini akan memberikan rekomendasi bagaimana cara meningkatkan prestasi belajar siswa yang mengacu pada kedua variabel tersebut.

\section{METODE}

Rancangan penelitian ini adalah korelasional dengan pendekatan kuantitatif karena menggunakan data yang berupa angka. Penelitian korelasional digunakan untuk menemukan ada atau tidaknya pengaruh atau hubungan antara dua va- 
riabel yaitu variabel bebas dan variabel terikat. Tujuannya adalah untuk mengetahui ada tidaknya hubungan dan pengaruh dari suatu fenomena, dan kalau ada berapa besar derajat hubungannya, antara beberapa variabel yang diteliti, walaupun tidak dapat diketahui apakah hubungan tersebut adalah hubungan sebab akibat ataupun bukan.

Selanjutnya, variabel bebas dalam penelitian ini adalah kecerdasan visual spasial $\left(\mathrm{X}_{1}\right)$ dan kemandirian belajar $\left(\mathrm{X}_{2}\right)$. Variabel terikat dalam penelitian ini adalah hasil belajar siswa (Y).

Smentara, populasi dalam penelitian ini adalah siswa kelas X Program Keahlian Teknik Pemesinan SMK Turen tahun ajaran 2017/2018 yang berjumlah 132 siswa. Sampel penelitian ini terdiri dari 3 kelas, yaitu kelas X TPm 2, X TPm 3, dan X TPm 4 yang berjumlah 82 siswa yang diambil menggunakan rumus slovin.

Instrumen yang digunakan dalam tes kecerdasan visual spasial adalah tes pilihan ganda. Variabel kecerdasan visual spasial memiliki 6 indikator dan setiap indikatornya diwakili tiga butir soal sehingga terdapat 18 butir soal pilihan ganda. Angket tertutup digunakan untuk mengetahui tingkat kemandirian belajar. Sementara itu, variabel kemandirian belajar memiliki 10 indikator dan setiap indikatornya terdapat 2 item, sehingga jumlahnya adalah 20 item.

Pengumpulan data penelitian ini dilakukan melalui dua cara, yaitu tes dan non tes. Pada variabel kecerdasan visual spasial dilakukan dengan tes, sedangkan pengumpulan data non tes dibagi menjadi dua, yaitu angket untuk mengetahui variabel kemandirian belajar dan dokumentasi nilai untuk mengetahui hasil belajar siswa.

Analisis data penelitian ini dilakukan dengan statistik regresi yang dengan bantuan program SPSS. Regresi linier digunakan untuk mengetahui hubungan antara dua variabel. Sementara, regresi berganda digunakan untuk mengetahui kontrubusi variabel kecerdasan visual spasial dan kemandirian belajar terhadap hasil belajar mata pelajaran Gambar Teknik I siswa SMK Turen secara bersamasama.

\section{HASIL}

Hasil analisis data hubungan dan pengaruh masing-masing variabel bebas terhadap variabel terikat ditunjukkan pada Tabel 1, Tabel 2, dan Tabel 3. Hubungan kecerdasan visual spasial terhadap hasil belajar siswa.

Tabel 1 menunjukkan bahwa nilai Sig. sebesar 0,000. Jika dibandingkan

Tabel 1. Hasil Uji Regresi Linier $\mathbf{X}_{1}$ terhadap Y

\begin{tabular}{cccc}
\hline $\mathbf{R}$ & $\begin{array}{c}\mathbf{R} \\
\text { Square }\end{array}$ & $\begin{array}{c}\text { Adjusted } \\
\text { R Square }\end{array}$ & $\begin{array}{c}\text { Std. Error } \\
\text { of the } \\
\text { Estimate }\end{array}$ \\
\hline, $890^{\mathrm{a}}$ &, 792 &, 789 & 2,144 \\
\hline
\end{tabular}

a. Predictors: (Constant), Kecerdasan Visual Spasial

Tabel 2. Hasil Uji Regresi Linier $\mathbf{X}_{2}$ terhadap Y

\begin{tabular}{cccc}
\hline $\mathbf{R}$ & $\begin{array}{c}\mathbf{R} \\
\text { Square }\end{array}$ & $\begin{array}{c}\text { Adjusted } \\
\text { R Square }\end{array}$ & $\begin{array}{c}\text { Std. Error } \\
\text { of the } \\
\text { Estimate }\end{array}$ \\
\hline, $943^{\text {a }}$ &, 889 &, 888 & 1,565 \\
\hline a. Predictors: Kemandirian belajar &
\end{tabular}

dengan $\alpha=0,05$, nilai Sig. lebih kecil daripada $\alpha($ Sig. $\leq \alpha)$, yaitu $0,000 \leq 0,05$. Artinya, Ho ditolak dan Ha diterima.

Dengan demikian, hal ini menunjukkan bahwa kecerdasan visual spasial $\left(\mathrm{X}_{1}\right)$ terdapat korelasi yang signifikan dengan hasil belajar (Y) pada siswa kelas X program keahlian teknik pemesinan di SMK Turen. Besarnya hubungan kecerdasan visual spasial $\left(\mathrm{X}_{1}\right)$ secara individual dengan hasil belajar (Y) adalah sebesar $79,20 \%$. 
Tabel 3. Hasil Uji Regresi Ganda

\begin{tabular}{|c|c|c|c|c|c|}
\hline \multirow[b]{2}{*}{ Model } & \multicolumn{2}{|c|}{$\begin{array}{l}\text { Unstandardized } \\
\text { Coefficients }\end{array}$} & $\begin{array}{l}\text { Standardized } \\
\text { Coefficients }\end{array}$ & \multirow[b]{2}{*}{$\mathrm{t}$} & \multirow[b]{2}{*}{ Sig. } \\
\hline & $\mathrm{B}$ & Std. Error & Beta & & \\
\hline 1 (Constant) & 50,467 & 1,524 & & 33,115 & 000 \\
\hline $\begin{array}{l}\text { Kecerdasan } \\
\text { Visual } \\
\text { Spasial }\end{array}$ & ,396 & ,087 & ,300 & 4,561 & ,000 \\
\hline $\begin{array}{l}\text { Kemandirian } \\
\text { Belajar }\end{array}$ & ,500 & ,048 & 684 & 10,408 & ,000 \\
\hline
\end{tabular}

Hubungan kemandirian belajar terhadap hasil belajar siswa. Tabel 2 menunjukkan nilai Sig. sebesar 0,000. Jika dibandingkan dengan $\alpha=0,05$, nilai Sig. lebih kecil daripada $\alpha($ Sig. $\leq \alpha)$, yaitu $0,000 \leq 0,05$. Artinya, Ho ditolak dan $\mathrm{Ha}$ diterima. Dengan demikian, hal ini menunjukkan bahwa kemandirian belajar $\left(\mathrm{X}_{2}\right)$ terdapat korelasi yang signifikan dengan hasil belajar siswa (Y) pada siswa kelas $\mathrm{X}$ program keahlian teknik pemesinan di SMK Turen. Besarnya hubungan kemandirian belajar $\left(\mathrm{X}_{2}\right)$ secara individual dengan hasil belajar siswa kelas X mata pelajaran gambar teknik I (Y) adalah sebesar 88,90\%.

Hubungan kecerdasan visual spasial dan kemandirian belajar terhadap hasil belajar siswa. Hasil uji signifikansi seperti pada Tabel 3 menunjukkan nilai Sig. sebesar 0,000. Jika dibandingkan dengan $\alpha=0,05$, nilai Sig. lebih kecil daripada $\alpha($ Sig. $\leq \alpha)$, yaitu $0,000 \leq 0,05$. Artinya, Ho ditolak dan Ha diterima. Dengan demikian hal ini menunjukkan bahwa $\mathrm{X}\left(\mathrm{X}_{1}, \mathrm{X}_{2}\right)$ terdapat korelasi secara simultan dan signifikan dengan hasil belajar siswa (Y) pada siswa kelas X program keahlian teknik pemesinan di SMK Turen. Besarnya hubungan kecerdasan visual spasial $\left(\mathrm{X}_{1}\right)$, kemandirian belajar $\left(\mathrm{X}_{2}\right)$ secara simultan dengan hasil belajar siswa (Y) adalah sebesar 91,20\%.

\section{PEMBAHASAN}

Pembahasan ini dibagi menjadi tiga bagian: (1) hubungan kecerdasan visual spasial dengan hasil belajar siswa, (2) hubungan kemandirian belajar dengan hasil belajar siswa, dan (3) hubungan kecerdasan visual spasial dan kemandirian belajar dengan hasil belajar siswa. Berikut ini adalah pembahasannya.

Pertama, untuk hubungan kecerdasan visual spasial dengan hasil belajar siswa pada mata pelajaran Gambar Teknik I di SMK Turen, hasil uji signifikansi pada Tabel 3 menunjukkan bahwa p-value adalah 0,000. Ini dapat disimpulkan bahwa terdapat hubungan positif dan signifikan antara kecerdasan visual spasial dengan hasil belajar siswa kelas $\mathrm{X}$ pada mata pelajaran gambar teknik I di SMK Turen. Ini memberikan informasi bahwa semakin tinggi kecerdasan visual spasial yang dimiliki oleh siswa, maka akan semakin tinggi pula hasil belajar siswa kelas X pada mata pelajaran Gambar Teknik I. Sehingga diharapkan, kecerdasan visual spasial yang tinggi dapat meningkat kemampuan siswa dalam menggambar teknik dalam menunjang hasil belajar siswa.

Penelitian Gani, Safitri, dan Mahyana (2017) menunjukkan bahwa kecerdasan spasial visual dapat meningkatkan hasil belajar siswa. Setiap aspek penilaian terintegrasi saling melengkapi sehingga siswa dapat tumbuh sesuai dengan keterampilan yang mereka miliki. Kegiatan yang dilakukan untuk meningkatkan kecerdasan visual spasial dapat dipilih sesuai dengan tingkat siswa. Sementara menganalisis pengaruh suatu benda, 
dapat diperhatikan dari ciri-ciri pribadi dari siswa, persepsi mereka datang dari perbedaan individu dan kecenderungan mereka (Yenilmez dan Kakmaci, 2015). Ini disimpulkan bahwa kecerdasan visual spasial dapat dikatakan berkembang dengan baik jika siswa mempunyai kapasitas mengelola gambar, bentuk, dan ruang tiga dimensi dengan aktivitas utama mengenali bentuk, warna, dan ruang serta menciptakan gambar secara mental maupun realistis sehingga dengan kecerdasan spasial yang dimiliki, siswa akan mengerahkan kemampuan dan usahanya untuk mencapai hasil gambar teknik yang diharapkan secara maksimal.

Dengan demikian, ini dapat dikatakan bahwa jika semakin tinggi kecerdasan visual spasial siswa maka ini akan meningkatkan hasil belajar siswa Kelas X pada Mata Pelajaran Gambar Teknik I di SMK Turen. Hubungan kecerdasan visual spasial dengan hasil belajar siswa Kelas X pada Mata Pelajaran Gambar Teknik I mempunyai hubungan yang positif dan signifikan, serta kategori tinggi, sehingga kecerdasan visual spasial dapat digunakan sebagai penentu tingginya prestasi hasil belajar siswa Kelas X pada Mata Pelajaran Gambar Teknik I di SMK Turen. Namun hasil belajar siswa ini juga dapat dipengaruhi oleh faktor lain, seperti faktor internal dan faktor eksternal dari siswa itu sendiri.

Kedua, untuk hubungan kemandirian belajar dengan hasil belajar siswa pada Mata Pelajaran Gambar Teknik I di SMK Turen, hasil uji signifikansi menunjukkan bahwa nilai signifikansi p sebesar 0.000 $<0,05$. Ini dapat disimpulkan bahwa terdapat hubungan positif dan signifikan antara kemandirian belajar dengan hasil belajar siswa Kelas X pada Mata Pelajaran Gambar Teknik I di SMK Turen. Hal ini memberikan informasi bahwa jika semakin tinggi kemandirian belajar yang dimiliki oleh siswa, maka ini akan semakin tinggi pula hasil belajar siswa Kelas X pada Mata Pelajaran Gambar
Teknik I di SMK Turen. Ini diharapkan bahwa kemandirian belajar yang tinggi dapat meningkatkan kemampuan siswa dalam menggambar teknik sehingga ini akan menunjang hasil belajar siswa.

Kemandirian belajar adalah individu yang secara aktif terlibat dalam lingkungan belajar, mengatur melatih, dan menggunakan kemampuannya secara efektif, dan memiliki keyakinan motivasi yang positif tentang kemampuannya dalam pembelajaran (Akareem dan Hossain, 2016; Armbruster, dkk., 2009; Iwamoto, dkk. 2017). Tidak adanya kemandirian pada siswa akan menghasilkan berbagai macam problem perilaku, misalnya pemalu, tidak punya motivasi sekolah, dan kebiasaan belajar yang jelek. Hal ini sesuai dengan hasil penelitian Kurniawati, dkk. (2015) bahwa siswa yang memiliki kemandirian belajar tinggi dapat mencapai hasil yang lebih baik dibanding siswa yang memiliki kemandirian belajar yang rendah. Oleh karena itu kemandirian belajar perlu untuk ditingkatkan karena dampak dari rendahnya kemandirian belajar pada siswa akan berpengaruh pada kemampuan siswa dalam mengelola dirinya sendiri untuk belajar serta akan berdampak pula pada kualitas belajar. Prestasi siswa akan ketergantungan oleh peran pembimbing atau guru saat akan belajar.

Dengan demikian, ini dapat dikatakan bahwa semakin tinggi kemandirian belajar siswa maka akan meningkatkan hasil belajar siswa Kelas X pada Mata Pelajaran Gambar Teknik I di SMK Turen. Hubungan kemandirian belajar dengan hasil belajar siswa Kelas X Mata Pelajaran Gambar Teknik I mempuyai hubungan yang positif dan signifikan, serta dalam kategori tinggi. Sehingga kemandirian belajar dapat digunakan sebagai penentu tingginya prestasi hasil belajar siswa. Namun hasil belajar siswa kelas X pada mata pelajaran gambar teknik I juga dapat dipengaruhi oleh faktor 
lain, seperti faktor internal dan faktor eksternal dari siswa itu sendiri.

Terakhir, untuk hubungan kecerdasan visual spasial dan kemandirian belajar dengan hasil belajar siswa pada Mata Pelajaran Gambar Teknik I di SMK Turen, hasil uji signifikansi juga menunjukkan bahwa nilai signifikansi $\mathrm{p}$ sebesar $0.000<0,05$. Hal ini dapat disimpulkan bahwa terdapat korelasi positif dan signifikan antara kecerdasan visual spasial dan kemandirian belajar dengan hasil belajar siswa Kelas X Mata Pelajaran Gambar Teknik I SMK Turen. Data ini memberikan informasi bahwa semakin tinggi kecerdasan visual spasial dan kemandirian belajar yang dimiliki oleh siswa, maka akan semakin tinggi pula hasil belajar siswa Kelas X Mata Pelajaran Gambar Teknik I SMK Turen. Sehingga ini diharapkan bahwa kecerdasan visual spasial dan kemandirian belajar yang tinggi dapat meningkat kemampuan siswa pada menggambar teknik. Namun demikian pada Tabel 3 menunjukkan bahwa variabel kemandirian siswa memiliki kontribusi yang lebih tinggi dibandingkan dengan variabel kecerdasan visual spasial.

Dalam penelitian Rimbatmojo, Kusmayadi, dan Riyadi (2017) menyatakan bahwa siswa dengan kecerdasan visual spasial tinggi tidak memiliki kesulitan pada setiap aspek metakognisi. Siswa dengan kecerdasan visual spasial sedang memiliki kesulitan pada aspek pengetahuan tentang strategi dan tugas-tugas kognitif, dan siswa dengan kecerdasan visual spasial rendah mengalami kesulitan pada tiga aspek metakognitif, yaitu pengetahuan tentang strategi, tugas-tugas kognitif dan pengetahuan diri. Kecerdasan visual spasial yang tinggi akan mempermudah siswa dalam memahami obyek geometri karena memiliki kemampuan untuk merasakan dunia spasial atau ruang secara akurat (Riastuti, dkk., 2017; Turgut dan Uygan, 2015; Yenilmez dan Kakmaci, 2015; Wahab, Abdullah, dkk.
2018). Hal ini menunjukkan bahwa kecerdasan visual spasial memiliki pengaruh yang tinggi dalam menggambar teknik.

Menurut penelitian Fahmy, dkk. (2018) menyatakan bahwa individu yang memiliki kemandirian belajar tinggi cenderung belajar lebih baik, mampu memantau, mengevaluasi, mengatur belajarnya secara efektif, menghemat waktu dalam menyelesaikan tugasnya, mengatur belajar dan waktu secara efisien, dan memperoleh skor yang tinggi dalam sains. Oleh karena itu kemandirian menjadi hal yang perlu diamati dan diperhatikan.

Dengan demikian, kecerdasan visual spasial dan kemandirian belajar siswa memberikan kontribusi terhadap hasil belajar siswa kelas X Teknik Pemesinan di SMK Turen. Hubungan kecerdasan visual spasial dan kemandirian belajar dengan hasil belajar siswa kelas $\mathrm{X}$ mata pelajaran gambar teknik I mempuyai hubungan yang positif dan signifikan, serta dalam kategori tinggi, sehingga kecerdasan visual spasial dan kemandirian belajar telah dapat digunakan sebagai penentu tingginya prestasi hasil belajar siswa Kelas X pada Mata Pelajaran Gambar Teknik I SMK Turen. Namun, Berdasarkan hasil tersebut, hasil belajar siswa Kelas X pada Mata Pelajaran Gambar Teknik I SMK Turen juga dipengaruhi oleh faktor lain, seperti faktor internal dan faktor eksternal dari siswa itu sendiri. Sehingga, motivasi dari luar perlu diberikan baik dari orangtua maupun guru di sekolah.

\section{SIMPULAN DAN SARAN}

Berdasarkan hasil penelitian dan pembahasan yang telah diuraikan dapat diambil kesimpulan bahwa kecerdasan visual spasial siswa kelas $\mathrm{X}$ program keahlian teknik pemesinan pada mata pelajaran di SMK Turen termasuk dalam kriteria tinggi. Kecerdasan visual spasial memiliki hubungan positif dan signifikan 
terhadap hasil belajar siswa Kelas X pada Mata Pelajaran Gambar Teknik I SMK Turen. Hubungan kecerdasan visual spasial secara linier berpengaruh terhadap hasil belajar siswa sebesar $79,20 \%$ dan memiliki nilai signifikansi $\mathrm{p}$ sebesar 0,000 .

Sementara, kemandirian belajar siswa kelas X Program Keahlian Teknik Pemesinan di SMK Turen termasuk dalam kriteria tinggi. Kemandirian belajar memiliki hubungan positif dan signifikan terhadap hasil belajar siswa Kelas X pada Mata Pelajaran Gambar Teknik I SMK Turen. Hubungan kemandirian belajar secara individual terhadap hasil belajar siswa Kelas X Mata Pelajaran Gambar Teknik I adalah sebesar 88,90\% dan memiliki nilai signifikansi $p$ sebesar $0,000<0,05$, maka $\mathrm{H}_{0}$ ditolak dan $\mathrm{H}_{1}$ diterima.

Kecerdasan visual spasial dan kemandirian belajar siswa secara bersamasama memiliki hubungan positif dan signifikan terhadap hasil belajar siswa Kelas $\mathrm{X}$ Mata Pelajaran Gambar Teknik I. Hubungan kecerdasan visual spasial dan kemandirian belajar secara simultan dengan hasil belajar siswa Kelas X Mata Pelajaran Gambar Teknik I adalah sebesar $91,20 \%$ dan memiliki nilai signifikansi $\mathrm{p}$ sebesar $0,000<0,05$, maka $\mathrm{H}_{0}$ ditolak dan $\mathrm{H}_{1}$ diterima. Akhirnya, kontribusi variabel kemandirian belajar memiliki kontribusi lebih tinggi dari variabel kecerdasan visual spasial terhadap hasil belajar siswa SMK Turen. Sehingga keduannya perlu ditingkatkan untuk lebih berkontribusi terhadap hasil belajar Mata Pelajaran Gambar Teknik 1 sesuai dengan standar yang dibutuhkan oleh industri.

\section{DAFTAR RUJUKAN}

Akareem, H.S. \& Hossain, S.S. 2016. Determinants of education quality: what makes students' perception different? Open Review of Educational Research, 3(1): 52-67. doi:10.1080/23265507.2016.11551 67.

Armbruster, P., Patel, M., Johnson, E., \& Weiss, M. 2009. Active Learning and Student-Centered Pedagogy Improve Student Attitudes and Performance in Introductory Biology. CBE Life Sciences Education, 8(3): 203-13.

Cocodia, E.A. 2014. Cultural Perceptions of Human Intelligence. Journal of Intelligence, 2(4): 180-196.

Direktorat Pembinaan SMK. 2018. Bantuan Modal Pengembangan Kelas Wirausaha. www.psmk. kemdikbud.go.id diakses 25 Maret 2018.

Fahmy, A. F. R., Wardono., \& Masrukan. 2018. Kemampuan Literasi Matematika dan Kemandirian Belajar Siswa pada Model Pembelajaran Rme Berbantuan Geogebra. PRISMA, 1, 59-567.

Gani, A., Safitri, R., \& Mahyana, M. 2017. Improving the Visual-Spatial Intelligence and Results of Learning of Junior High School Students' with Multiple IntelligencesBased Students Worksheet Learning of Lens Materials. Jurnal Pendidikan IPA Indonesia, 6 (1): 1622.

Gardner, H. 1993. Multiple Intelligence: The Theory in Practice. New York: Basic Books.

Iwamoto, D.H., Hargis, J., Bordner, R., \& Chandler, P. 2017. Self-Regulation Learning as a Critical Attribute for Succesful Teaching and Learning. International Journal for the Scholarship of Teaching and Learning, 11(2): Article 7.

Kurniawati, M., Junaedi, I., \& Mariani, S. 2015. Analisis Karakteristik Berpikir Geometri dan Kemandirian Belajar dalam pembelajaran Fase Van Hiele Berbantuan Geometers 
Sketchpad. Journal of Mathematics Education Research, 4(2): 102-107. Novitasari, D. \& Rahman, A. 2015. Profil Kreativitas Siswa dalam Pemecahan Masalah Matematika Ditinjau dari Kecerdasan Visual Spasial dan Logis Matematis pada Siswa SMAN 3 Makasar. Daya Matematis: Jurnal Inovasi Pendidikan Matematika, 3(1): 41-50.

Pangestu, S.M. 2017. Pengaruh Tingkat Kedisiplinan Belajar dan Kemandirian Belajar Mata Pelajaran Ekonomi Kelas XII IIS SMA Negeri 1 Kepanjen. Malang: Universitas Negeri Malang.

Permendiknas No. 23 Tahun 2006 tentang Standar Kompetensi Lulusan untuk Satuan Pendidikan Dasar dan Menengah.

Riastuti, N., Mardiyana, \& Pramudya, I. 2017. Analisis Keterampilan Geometri Siswa Dilihat dari Tata Ruang Intelijen. Surakarta: Pascasarjana Universitas Sebelas Maret.

Rimbatmojo, S., Kusmayadi, T.A., \& Riyadi, R. 2017. Metacognition Difficulty of Students with VisualSpatial Intelligence during Solving Open-Ended Problem. Journal of Physics: Conference Series, 895, 012034.
Sumarno, U. 2004. Kemandirian Belajar: Apa, Mengapa, dan Bagaimana Dikembangkan Pada Peserta Didik. Bandung: FPMIPA UPI.

Suratman, J.O. 2000. Menggambar Teknik Mesin. Bandung: Pustaka Grafika.

Tirtarahardja, U. \& Sulo, L. 2008. Pengantar Pendidikan. Jakarta: Rineka Cipta.

Turgut, M. \& Uygan, C. 2015. Designing Spatial Visualization Tasks for Middle School Students with 3D Modeling Software: An Instrumental Approach. International Journal for Technology in Mathematics Education, 22(2): 45-52.

Wahab, R.A., Abdullah, A.H., Abu, M.S., Atan, N.A., Mokhtar, M., \& Hamzah, M.H. 2018. A learning 3D Geometry Through Sketchup Make (SPPD-SUM) to Enhance Visual Spatial Skills and the Level of Geometric Thinking. Journal of Fundamental and Applied Sciences, 10(6S), 1005-1039.

Yenilmez, K. \& Kakmaci, O. 2015. Investigasi Hubungan antara Tata Ruang Visualisasi Sukses dan Kemampuan Spasial/Kecerdasan Spasial Siswa Kelas VI. International Journal of Instruction, 8(1): 190204. 